\title{
腹腔鏡下に治療し得た腹膜妊娠の4症例
}

浜の町病院

山本奈理、竹内麗子、井桘大介、弓削乃利人、宮㟝順秀、

安永昌史、江頭活子、上岡陽亮、井上善仁

\section{Successful Laparoscopic Surgery for an Abdominal Pregnancy: Report of Four Cases}

\author{
Nari Yamamoto, Reiko Takeuchi, Daisuke Izuchi, Norihito Yuge, Masahide Miyazaki, \\ Masafumi Yasunaga, Katsuko Egashira, Yousuke Ueoka, Yoshihito Inoue \\ Department of Obstetrics and Gynecology, Hamanomachi Hospital
}

\begin{abstract}
Case Report: Approximately 1\% of ectopic pregnancies are abdominal pregnancies; these pregnancies may be life threatening. We present four cases in which abdominal pregnancy was successfully managed by operative laparoscopy and two cases in which abdominal pregnancy was managed by laparotomy, together with a review of the published literature. In the four cases, which were managed by laparoscopy, the products of conception and blood clots were resected laparoscopically with controlled hemostasis. In two cases, conversion from a laparoscopy to a laparotomy was necessary because bleeding at the implantation site was uncontrollable. Operative laparoscopy is an appropriate method for the treatment of an abdominal pregnancy when the site of implantation does not involve the surface of the intestinal tract. However, abdominal pregnancy accompanied by active bleeding from the site may require conversion from laparoscopy to laparotomy.
\end{abstract}

Key words: peritoneal pregnancy, abdominal pregnancy, laparoscopic surgery

\section{緒言}

腹膜妊娠は異所性妊娠の中で $1 \%$ 以下の頻度で あり、比較的まれな疾患である1)。通常の異所性 妊娠と比較すると約7.7倍も死亡率が高いとの報 告もあり ${ }^{2)}$ 、早期発見および適切な治療が望まれ る。現在では異所性妊娠に対する手術療法は腹腔 鏡下手術が一般的であり、腹膜妊娠に対しても腹 腔鏡下手術で治療可能であったとの報告が散見さ れる。一般的に腹膜妊娠は術前の確定診断が難し く、術中に腹膜妊娠と診断がつくことがほとんど であり、このような場合にも腹腔鏡下手術はより 詳細に腹腔内を観察することができるため非常に 優れた術式である。平成 9 年 4 月から平成 24 年 3 月までの 15 年間に当院で手術を施行した異所性妊
娠は565例で部位別では卵管妊娠が520例（92.0\%） と最も多く、次いで間質部妊娠 21 例 $(3.7 \%)$ 、卵 巣妊娠 16 例 $(2.8 \%)$ 、腹膜妊娠 6 例 $(1.0 \%)$ 、頚 管妊娠 1 例 $(0.1 \%)$ 、帝王切開瘏痕部妊娠 1 例 $(0.1$ \%）であった。腹膜妊娠6例のうち腹腔鏡下に治 療し得たのは 4 症例であった。今回この 4 症例と 開腹術を施行した 2 症例を比較し、腹膜妊娠に対 する外科治療としての腹腔鏡手術の意義を検討し た。

\section{症例}

【患者 $1 】 29$ 歳 1 経妊 0 経産（自然流産 1 回） 現病歴：近医でクロミフェン内服、タイミング法 を行っていた。自然流産後、月経再来せず妊娠反 応陽性となり、下腹部痛を認めたため基礎体温か 
ら妊娠 6 週 0 日に当科紹介となった。超音波検査 で子宮内に胎囊を認めず、両側付属器に異常なく 骨盤内にecho free spaceを認めなかった。血液検 查で血中hCG899IU/L、血色素量 $12.4 \mathrm{~g} / \mathrm{dl}$ であり、 腹痛は軽快したため経過観察した。妊娠 6 週 2 日 の血液検査で血中hCG1,360IU/Lとなり、超音波 検查で子宮内に胎囊を認めず同日、子宮内容除去 術を施行した。子宮内容除去術後 2 日の血液検査 でhCG1,804IU/Lに上昇しており超音波検査で子 宮内に胎囊を認めず異所性妊娠を疑い、着床部位 は明らかではなかったが診断と治療をかねて妊娠 6 週 5 日に腹腔鏡下手術を施行した。腹腔内出血 を $100 \mathrm{ml}$ 認め、子宮、両側卵管、卵巣に異常は認 めず、膀胱子宮窩腹膜に着床部位を認めた（図 1 、 2 )。絨毛組織を膀胱子宮窩腹膜から剥離し、剥 離後の出血はモノポーラーで止血した。術中出血 量は少量で、摘出標本の病理組織診でchorionic villiを認め（図 3 ）腹膜妊娠の診断に至った。術 後 4 日に退院となり、術後20日の血液検查で hCG3IU/Lとなった。

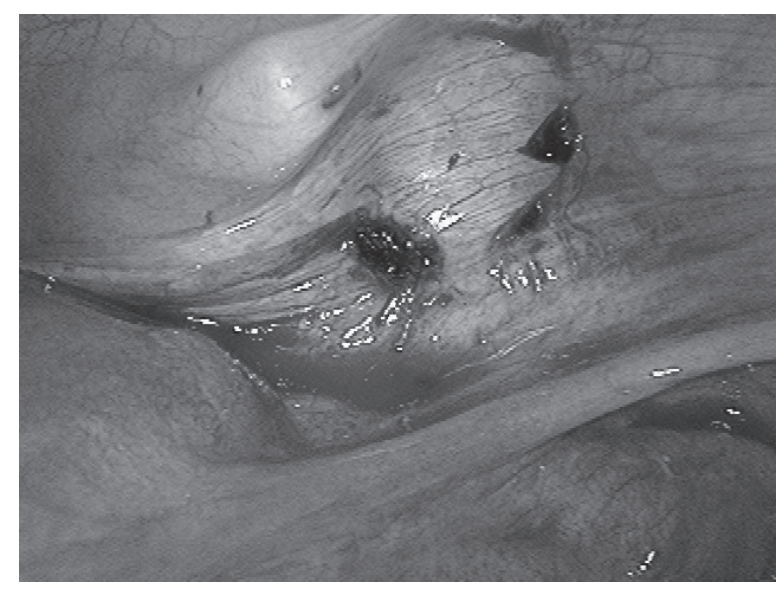

図 1

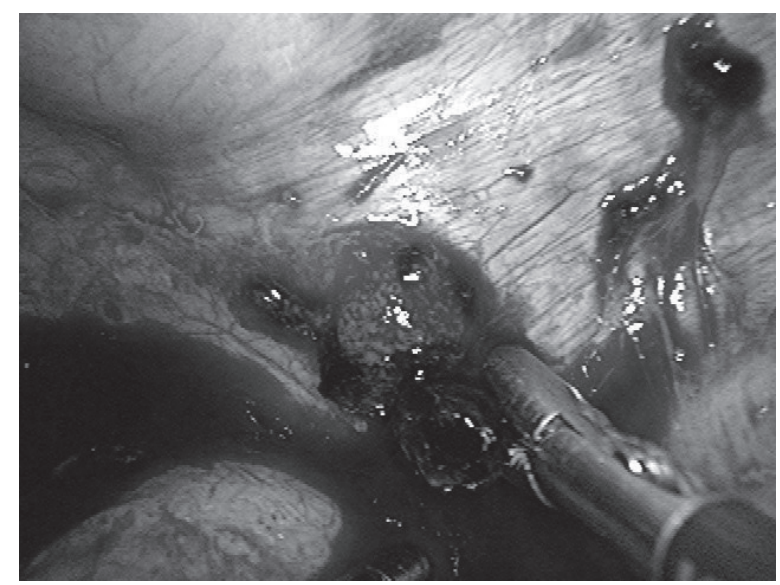

図 2

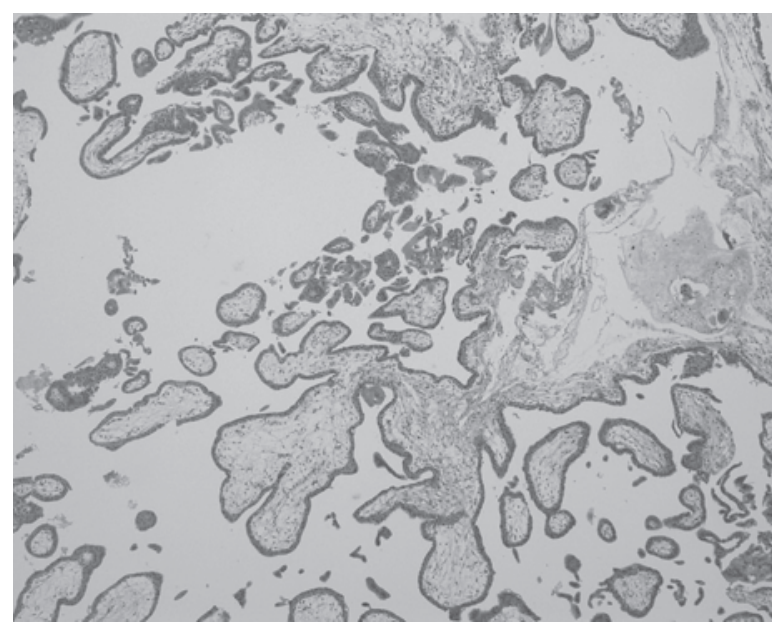

図3

【患者 2】32歳 0 経妊 0 経産

現病歴：下腹部痛のため近医を受診し、妊娠反応 陽性で異所性妊娠が疑われ、最終月経から妊娠 4 週 5 日に当科へ救急搬送となった。超音波検査で 子宮内に胎囊を認めず、右卵巣近傍に $2.3 \mathrm{~cm}$ の腫 瘤を認め、ダグラス窩にecho free spaceを認めた。 血液検査でhCG3,274IU/L、血色素量 $11.7 \mathrm{~g} / \mathrm{dl}$ であ った。右卵管妊娠の診断で腹腔鏡下手術を施行し た。腹腔内出血を $200 \mathrm{ml}$ 認め、子宮、両側卵管、 卵巣に異常は認めず、左仙骨子宮勒帯直上に 4 $\mathrm{cm}$ の血腫と内部に $1 \mathrm{~cm}$ の胎囊を認めた（図 4 ）。 血腫を剥離し、剥離後の出血はバイポーラーで止 血した。術中出血量は $5 \mathrm{~g}$ で、摘出標本の病理組 織診でchorionic villiを認め（図 5 ) 腹膜妊娠の診 断に至った。術後 5 日に退院となり、術後18日の 血液検査でhCG6IU/Lとなった。

【患者 3】31歳 0 経妊 0 経産 現病歴：近医で通水検查を施行した周期に自然妊 娠成立した。続発性無月経、腹痛のため同院を再

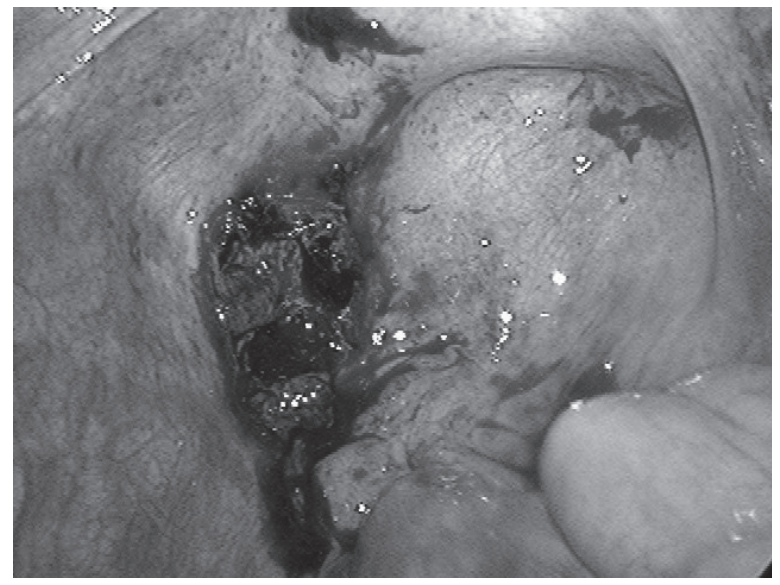

図 4 


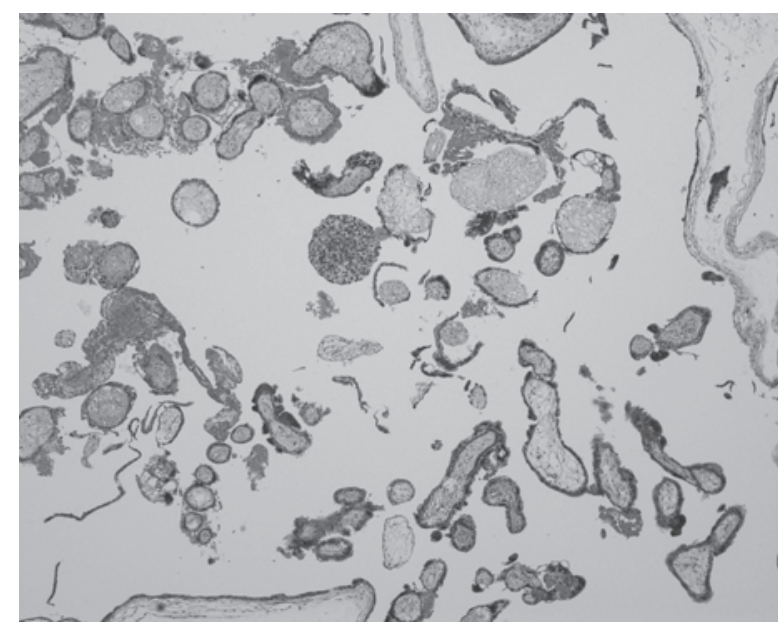

図 5

診し異所性妊娠が疑われ当科に紹介となった。超 音波検査で子宮内に胎囊を認めず、子宮左側に $3.9 \mathrm{~cm}$ の胎囊および $1.7 \mathrm{~cm}$ の胎児（妊娠 8 週 5 日 相当)、胎児心拍を認めた。ダグラス窩にecho free spaceを認めた。左卵管間質部妊娠の診断で 腹腔鏡下手術を施行した。腹腔内出血を $200 \mathrm{ml}$ 認 め、子宮、両側卵管、卵巣に異常は認めず、左膀 胱子宮窩腹膜に $4 \mathrm{~cm}$ の血腫と、内部に胎囊、胎 児を認めた。血腫を剥離し、剥離後の出血はモノ ポーラーで止血した。術中出血量は少量で、摘出 標本の病理組織診でchorionic villiを認め腹膜妊 娠の診断に至った。術後 5 日に退院となり、術後 18日の血液検査でhCG24IU/Lとなった。

【患者 4】32歳 0 経妊 0 経産

現病歴：原発性不妊症に対して31歳時に腹腔鏡下 右卵管采開口術を施行した。術後 1 年経過して human menopausal gonadotropin投与、タイミン グ法で妊娠成立した。最終月経から妊娠 6 週 0 日 の尿検査でhCG4,000IU/L陽性であり、超音波検 查で子宮内に胎囊を認めず、骨盤内にecho free spaceを認めなかった。血液検查で血色素量 $12.6 \mathrm{~g} / \mathrm{dl}$ であった。異所性妊娠が疑われ同日、子 宮内容除去術を施行した。子宮内容除去術後 2 日 （妊娠 6 週 2 日）の尿検查でhCG4,000IU/L陽性の ままであり超音波検查で子宮内に胎囊を認めず異 所性妊娠を疑い着床部位は明らかではなかった が、診断と治療をかねて妊娠 6 週 3 日に腹腔鏡下 手術を施行した。腹腔内出血を認めず、子宮、両 側卵管、卵巣に異常なく、左ダグラス窩に $1 \mathrm{~cm}$ 大の囊胞を認めた。囊胞を切除し、切除後の出血 はバイポーラーで止血した。術中出血量は少量で、 摘出標本の病理組織診でchorionic villiを認め腹膜
妊娠の診断に至った。術後 4 日に退院し、術後 7 日の尿検査でhCG50IU/Lとなった。

\section{【患者 5】35歳 0 経妊 0 経産}

現病歴：続発性無月経、下腹部痛のため近医を受 診し、異所性妊娠が疑われ当科に紹介となった。 尿検查でhCG2,000IU/L陽性であり超音波検查で 子宮内に胎囊を認めず、右付属器領域に圧痛を認 めた。血液検查で血色素量 $12.6 \mathrm{~g} / \mathrm{dl}$ であった。右 卵管妊娠の診断で腹腔鏡下手術を施行予定であっ たが、来院45分後に気分不良、嘔気、嘔吐、顔面 蒼白となり、血圧 $60 / 30 \mathrm{mmHg}$ 、心拍数 66 回/分 となったため 20 分後に開腹術を開始した。腹腔内 出血を $500 \mathrm{ml}$ 認め、子宮、両側卵管、卵巣に異常 なく、膀胱子宮窩腹膜に $2 \mathrm{~cm}$ の血腫を認め、血 腫から活動性の出血が持続していた。血腫を摘出 し、摘出部の出血を縫合止血した。術中出血量は $5 \mathrm{~g}$ で、摘出標本の病理組織診でchorionic villiを 認め腹膜妊娠の診断に至った。術後10日の尿検査 でhCG25IU/L以下となり退院した。

【患者 6】28歳 1 経妊 1 経産（22歳 経腟分娩） 現病歴：腹痛のため近医を受診し、妊娠反応陽性 であり超音波検查で子宮内に胎囊を認めず、異所 性妊娠が疑われ、最終月経から妊娠 9 週 0 日に当 科紹介となった。尿検査でhCG4,000IU/L陽性で あり、超音波検查で子宮内に胎囊を認めず、左付 属器領域に圧痛を認めた。血液検査で血色素量 $9.6 \mathrm{~g} / \mathrm{d}$ であった。左卵管妊娠の診断で腹腔鏡下 手術を施行した。腹腔内出血を $500 \mathrm{ml}$ 認め、子宮、 両側卵管、卵巣に異常は認めず、左仙骨子宮勒带 と左尿管の間に $1.5 \mathrm{~cm}$ の血腫を認め血腫から活動 性の出血が持続していた。左尿管ステントを挿入 後、血腫を摘出したが、摘出部からの出血が持続 し電気凝固での止血が困難であった。血色素量 $6.2 \mathrm{~g} / \mathrm{dl}$ に低下したため濃厚赤血球投与を開始し 開腹手術に変更した。血腫摘出部位を縫合止血し、 術中出血量は $500 \mathrm{~g}$ であり濃厚赤血球を4単位投与 した。摘出標本の病理組織診でchorionic villiを認 め腹膜妊娠の診断に至った。術後 7 日の尿検査で hCG100IU/Lとなり退院した。

\section{考察}

腹膜妊娠には原発性と続発性があり、原発性は 受精卵が腹膜面に直接着床するものであり、続発 性は卵管、卵巣などに着床した妊卵が腹腔内に流 れていき、腹膜に着床するものである。破裂症例 
などでは両者を厳密に鑑別することは難しいが、 大部分は続発性とされている。原発性腹膜妊娠の 診断基準として1942年にStuddifordらが(1)両側卵 管、卵巣が正常であり、破裂痕などが存在しない、 (2)子宮内腔と腹膜間に㾇孔形成がない、(3)着床部 が腹膜に限局しており卵管における原発性着床部 位からの続発性着床の可能性を否定できる、と提 唱している ${ }^{3)}$ 。1968年にはFriedrickらが Studdifordの報告を一部修正し、12週未満の症例 に限定している ${ }^{4)}$ 。腹膜妊娠の成立機序としては 諸説あるが受精卵がリンパ系を介して後腹膜に達 し着床が成立するとの報告 ${ }^{5)}$ や、受精卵がまず後 腹膜表面に達しトロホブラストの腹膜内への浸潤 により着床が成立するとの報告もある ${ }^{6)}$ 。病理組 織学的には腹膜組織、䄉毛の形成、そしてトロホ ブラストの存在を認めることが腹膜妊娠の証拠と なる。超音波検査と $\mathrm{hCG}$ 定量検査により異所性妊 娠の診断は比較的容易になってきたが、腹膜妊娠 を術前に診断するのは非常に困難である。異所性 妊娠を疑うが着床部位が明らかでない場合はMRI 検查が有用といわれている7)。MRI検查では絨毛 細胞は血流の豊富な細胞であるため造影剂の使用 により胎囊が明瞭に描出され、着床部位の同定が 可能となる。しかし異所性妊娠の多くは緊急性を 要し、時間のかかるMRI検査を行うことが困難な ことが多い。異所性妊娠を疑うが着床部位が不明 である場合には診断と治療を兼ねた腹腔鏡下手術 が有用と考えられる。腹腔鏡下手術は低侵襲であ り腹腔内全体の詳細な観察が可能である。両側卵 管、卵巣が正常であれば腹腔鏡により上腹部から 下腹部まで詳細に観察することができる。現在ま でに腹腔鏡下に治療し得た腹膜妊娠の報告例は自 験例を含め35例ある（表 1 ）。当院で経験した腹 膜妊娠 6 例の患者年齢は平均 31.1 歳、未産婦 5 例、 経産婦 1 例であった。治療時妊娠週数は平均 6 週、 生殖補助医療による妊娠はなかった。6 例中 1 例 は腹腔鏡下で絨毛組織を除去したが、止血困難で あり開腹術に変更した。1 例は腹腔鏡下手術予定 であったが、術直前に血圧低下を認め緊急開腹術 を施行した。 4 例は腹腔鏡下に治療し得た。病変 腫瘤径は平均 $2.2 \mathrm{~cm}$ であり、腹腔鏡下に治療し得 た症例は平均 $2.5 \mathrm{~cm}$ であった。腹腔内出血は平均 $250 \mathrm{ml}$ でり、腹腔鏡下に治療し得た症例は平均 $125 \mathrm{ml}$ であた。術中出血量は平均 $83.3 \mathrm{ml}$ であり、 腹腔鏡下に治療し得た症例は全て $5 \mathrm{ml}$ 以下であ った。術後にメソトキセート（MTX）を投与し た症例はなかった。腹膜妊娠の腹腔鏡下手術の適
応条件についてはまだ十分な議論はされていない が、Morita ${ }^{1)}$ 、松浦 ${ }^{7)}$ らは妊娠初期であり着床部 の血流が豊富な領域でないことが腹腔鏡手術によ る治療の適応条件であると述べている。Tsudoら は絨毛が広範囲に梁く侵入していないことが条件 としている8 ${ }^{8)}$ 。梅崎らは病巣径 $3 \mathrm{~cm}$ 以上の場合は 止血が十分に行えない可能性があり、腹腔鏡下手 術での治療が困難であるとしている9)。鈴木らは 妊娠 9 週未満、病巣 $4 \mathrm{~cm}$ 未満であるとしている ${ }^{10)}$ 。 中村らは妊娠初期であること、着床部が致命的重 要臓器を巻き込んでいないこととしている ${ }^{11}$ 。現 在までの報告例をみると病変 $4 \mathrm{~cm}$ 以上の症例は 自験例を含め 5 例あり ${ }^{1,10)}$ 、Siow らの症例は妊娠 10 週で病巣 $6.5 \mathrm{~cm}$ であるが腹腔鏡下に治療し得て いる ${ }^{12)}$ 。このことから病巣の大きさや妊娠週数の みで腹腔鏡の適応制限する必要はないと考えられ る。合志らは術中観察で着床部位周辺の栄養血管 の発達が著しい場合や尿管などの重要臟器に近接 しているような場合は摘出後の出血が制御困難に なる危険性が高く、開腹術を選択するべきと述べ ている ${ }^{13)}$ が、自験例のうち開腹術を施行した 2 例はバイタルサインの悪化により時間を要する腹 腔鏡下手術ではなく開腹手術を行った。妊娠初期 や病変腫瘤径が小さくても病変から活動性の出血 が認められる場合には、病変切除後の止血が困難 となり開腹術への変更や輸血が必要となる可能性 を念頭に置かなければならないが、診断とともに 処置が可能であり低侵襲な腹腔鏡下手術が腹膜妊 娠に対する外科的治療の第一選択であると考えら れる。近年では多量の出血を伴う子宮外妊娠症例 に対して自己血回収装置を使用し腹腔鏡下に治療 し得た例も報告されており ${ }^{14)}$ 、機器向上による腹 腔鏡下手術開始までの時間短縮や術中出血コント ロールが可能になれば腹腔鏡下で治療しえる症例 の増加が見込めると考えられる。着床部位が重要 臓器に隣接している場合には腹腔鏡下手術、開腹 手術に関わらず病変の摘出は困難であることが考 えられ、そのような場合にはMTXによる治療を 検討すべきであると考えられる。腹腔鏡下に治療 した腹膜妊娠の報告例の中で大網に小さな妊娠病 巣が点在していた鈴木らの症例 ${ }^{10)}$ は術後にMTX の投与を要したが、その他の症例はMTX投与す ることなく治療を完了できたと述べている。また 腹膜妊娠に対してMTXを全身投与または局所投 与し治療可能であったとの報告が4例あるが ${ }^{15,16)}$ 、 Cobellisの 3 症例は診断的腹腔鏡下手術を施行後 にMTXを全身投与しており、腸管に着床した腹 
表 1 腹腔鏡下に治療された腹膜妊娠の症例一覧

\begin{tabular}{|c|c|c|c|c|c|c|c|c|c|}
\hline 年度 & 報告者 & 年齢 & 経妊経産 & 週数 & 症状 & hCG (IU/L) & 腹腔内出血 $(\mathrm{ml})$ & 着床部位 & 腫瘤径 \\
\hline 2012 & 自験例 & 29 & G1P0 & $6+5$ & 腹痛 & 血中 1,804 & 100 & 膀胱子宮窩腹膜 & $1 \mathrm{~cm}$ \\
\hline 2012 & 自験例 & 32 & G0P0 & $4+5$ & 腹痛 & 血中 3,274 & 200 & 左仙骨子宮勒帯 & $4 \mathrm{~cm}$ \\
\hline 2012 & 自験例 & 31 & G0P0 & $8+5$ & 腹痛 & 胎児心拍 $(+)$ & 200 & 膀胱子宮窩腹膜 & $4 \mathrm{~cm}$ \\
\hline 2012 & 自験例 & 32 & G0P0 & $6+3$ & なし & 尿中 4,000 & なし & 左ダグラス窩 & $1 \mathrm{~cm}$ \\
\hline 2012 & 松浦、他 7) & 24 & G0P0 & 不明 & 腹痛 & 血中 4,778 & 1220 & 右仙骨子宮勒帯 & 不明 \\
\hline 2011 & HS Koo, et al20) & 32 & G1P0 & $6+0$ & なし & 血中 2,995 & 不明 & 左仙骨子宮勒带 & $2 \mathrm{~cm}$ \\
\hline 2011 & 香川、他 21) & 36 & G1P0 & $7+6$ & 性器出血 & 血中 2,511 & 中等量 & 大網 & 不明 \\
\hline 2011 & 香川、他 21) & 27 & $\mathrm{G} 2 \mathrm{P} 1$ & $6+1$ & 肛門痛 & 血中 1,853 & 中等量 & 左仙骨子宮勒带 & 不明 \\
\hline 2010 & 山本、他 22) & 30 & G1P0 & 不明 & 腟円蓋痛 & 血中 852 & 少量 & 左仙骨子宮勒带 & $2 \mathrm{~cm}$ \\
\hline 2010 & 合志、他 13) & 35 & G0P0 & $5+6$ & なし & 血中 4,899 & なし & 膀胱子宮窩腹膜 & $1 \mathrm{~cm}$ \\
\hline 2008 & 中澤、他 23) & 29 & G1P1 & $7+2$ & 腹痛 & \begin{tabular}{|l|} 
不明 \\
\end{tabular} & 47 & ダグラス窩右側 & $1 \mathrm{~cm}$ \\
\hline 2006 & 中村、他 11) & 33 & G1P1 & $6+5$ & 不正出血 & 尿中 8,000 & なし & 子宮体部後壁 & $2.5 \mathrm{~cm}$ \\
\hline 2004 & Siow A, et al ${ }^{12)}$ & 25 & 不明 & 10 & なし & 血中 55.8 & 不明 & 右広閒膜 & $6.5 \mathrm{~cm}$ \\
\hline 2004 & Gerli S, et al 24) & 21 & 不明 & 8 & なし & 血中 24,534 & 不明 & ダグラス窩 & $2 \mathrm{~cm}$ \\
\hline 2004 & 興石、他 25) & 30 & G0P0 & $9+4$ & 不正出血 & 血中 252 & 50 & ダグラス窩 & $2 \mathrm{~cm}$ \\
\hline 2004 & 三浦、他 26) & 26 & G1P1 & $7+2$ & 腹痛 & 血中 7,540 & 500 & 左仙骨子宮勒带 & $1.5 \mathrm{~cm}$ \\
\hline 2004 & 三浦、他 26) & 28 & G0P0 & $5+3$ & なし & 血中 27,000 & 30 & 左膀胱子宮勒带 & $2 \mathrm{~cm}$ \\
\hline 2004 & 岡本、他 27) & 38 & G0P0 & $9+3$ & なし & 血中 5,000 & 少量 & 右卵管、ダグラス窩 & $3 \mathrm{~cm}$ \\
\hline 2004 & 鈴木、他 10) & 27 & G0P0 & 7 & 腹痛 & 尿中 1,381 & 多量 & 子宮底部漿膜、右卵巣 & $3 \mathrm{~cm}$ \\
\hline 2004 & 鈴木、他 10) & 32 & G1P0 & 5 & 腹痛 & 尿中 3,298 & 不明 & 大網 & $5 \mathrm{~cm}$ \\
\hline 2003 & $\begin{array}{l}\text { Chang CK, et } \\
\mathrm{al}^{28)}\end{array}$ & 28 & G4P1 & 5 & 腹痛 & 尿中 $\mathrm{hCG}(+)$ & 不明 & 大網 & 不明 \\
\hline 2002 & $\begin{array}{l}\text { Chung MT, et } \\
\mathrm{al}^{29)}\end{array}$ & 16 & G0P0 & 8 & 腹痛 & 尿中 $\mathrm{hCG}(+)$ & 多量 & 大網 & $1.5 \mathrm{~cm}$ \\
\hline 2002 & Kwok A, et al ${ }^{30)}$ & 32 & G2P1 & 12 & \begin{tabular}{|l} 
嘔気 \\
乳房痛
\end{tabular} & 14 & 不明 & ダグラス窩 & $2 \mathrm{~cm}$ \\
\hline 2003 & 仲村、他 31) & 23 & G0P0 & $9+6$ & 不正出血 & 尿中 732 & 少量 & 左仙骨子宮勒带 & $1 \mathrm{~cm}$ \\
\hline 2001 & 矢野 32$)$ & 35 & G0P0 & $7+6$ & なし & 血中 492 & なし & $\begin{array}{l}\text { 膀胱子宮窩之 } \\
\text { 左円勒带の間 }\end{array}$ & 不明 \\
\hline 2001 & 千々和、他 33) & 33 & G0P0 & $8+4$ & なし & 尿中 9,600 & 少量 & 左膀胱子宮勒帯 & $1 \mathrm{~cm}$ \\
\hline 2001 & 斉藤、他 34) & 33 & G0P0 & $5+3$ & 腹痛 & 尿中 2,000 & 500 & 右ダグラス窩 & 不明 \\
\hline 2001 & $\begin{array}{l}\text { Ginath S, et al } \\
35)\end{array}$ & 31 & G7P5 & 7 & 腹痛 & 血中 830 & 1700 & 左仙骨子宮勒带 & $2.5 \mathrm{~cm}$ \\
\hline 2000 & $\begin{array}{l}\text { Geisher JP, et al } \\
\text { 36) }\end{array}$ & 32 & 不明 & 4 & 腹痛 & 血中 543 & 500 & $\begin{array}{l}\text { 右仙骨子宮勒带と直腸 } \\
\text { の間 }\end{array}$ & 不明 \\
\hline 1997 & Tsudo T, et al ${ }^{8)}$ & 29 & G0P0 & $7+3$ & 腹痛 & 不明 & 150 & 右膀胱子宮窩 & $2.7 \mathrm{~cm}$ \\
\hline 1996 & Del Rosario $\mathrm{R}^{19)}$ & 35 & G0P0 & $10+2$ & 腹痛 & 血中 563 & 20 & 膀胱子宮窩腹膜 & $1.5 \mathrm{~cm}$ \\
\hline 1996 & Morita Y, et al 1) & 25 & G0P0 & 6 & 腹痛 & 尿中 2,137 & 50 & 子宮後壁漿膜面 & $6 \mathrm{~cm}$ \\
\hline 1996 & ME.Olsen ${ }^{37)}$ & 26 & G1P1 & 7 & 不正出血 & 22,140 & 不明 & 右勒带 & 不明 \\
\hline 1995 & $\begin{array}{l}\text { Ben Refael Z, et } \\
\text { al }{ }^{38)}\end{array}$ & 35 & G3P2 & 8 & 腹痛 & 6,930 & 少量 & 虫垂 & $2 \mathrm{~cm}$ \\
\hline 1995 & $\begin{array}{l}\text { Dover RW, et al } \\
\text { 39) }\end{array}$ & 27 & 経産婦 & $6+3$ & 腹痛 & 血中 32 & 100 & 上行結腸表面 & 不明 \\
\hline
\end{tabular}

膜妊娠の場合には診断的腹腔鏡にとどめ、MTX で治療すべきと述べている ${ }^{16)}$ 。腹膜妊娠に対して MTXを使用し急速な組織壊死によると思われる 敗血症や死亡例が報告されている ${ }^{17)}$ 。また現在ま での腹腔鏡下に治療し得た腹膜妊娠の報告例のな かには着床部位不明の異所性妊娠と診断され
MTXを投与されていたが腹痛が出現し腹腔鏡下 手術を施行され治療している症例が 2 例ある ${ }^{18,19) 。 ~}$ これらのことから安易にMTXを全身投与するこ とは控え、診断とともに処置可能である腹腔鏡下 手術が腹膜妊娠に対する治療の第一選択であると 考えられる。 


\section{結語}

腹腔鏡下に治療し得た腹膜妊娠の 4 症例と、腹 腔鏡手術から開腹術に変更した腹膜妊娠の 2 症例 を経験した。技術や機器の向上により腹腔鏡下手 術の適応範囲は日々、拡大しており腹膜妊娠に対 しても腹腔鏡下手術を試みられる機会が増えるこ とが予想される。腹膜妊娠は死亡率の高い疾患で 適切な治療が必要であり、腹膜妊娠に対する腹腔 鏡下手術の適応と限界について更なる検討が望ま れる。

本論文の要旨は第 52 回日本産科婦人科内視鏡学 会において発表した。

\section{参考文献}

1) Morita Y, et al.: Successful laparoscopic management of primary abdominal pregnancy. Hum Reprod 1996; 11: 2546-2547.

2 ) Joong SS, et al.: Primary peritoneal pregnancy implanted on the uterosacral ligament: A case report. J Korean Med Sci 2000; 15: 359-362.

3 ) Studdiford WE:: Primary peritoneal pregnancy. Am J Obstet Gynecol 1942; 44: 487-491.

4) Friedrich EG, et al.: Primary pelvic peritoneal pregnancy. Obstet Gynecol 1968; 31: 649-653.

5 ) Hall JS, et al.: Retroperitoneal ectopic pregnancy. J Obstet Gynecol Br Commonw 1973; 80: 92-94.

6) Ferland RJ, et al.: An ectopic pregnancy in the upper retroperitoneum following in vitro fertilization and embryo transfer. Obstet Gynecol 1991; 78: 544-546.

7 ）松浦基樹 他：腹腔鏡下に治療し得た腹膜妊娠の1例、 産科と婦人科、2012;79:123-126.

$8)$ Tsudo $T$, et al.: Laparoscopic management of early primary abdominal pregnancy. Obstet Gynecol 1997; 90: 687.

9）梅崎美奈 他：腹腔鏡下手術が困難であった子宮広間 膜後面に着床した腹膜妊娠の一例、日産内視鏡誌、 $2003 ; 19: 177$.

10）鈴木りか 他：腹胿鏡下に治療した腹胿娃娠の 2 症例、 日産内視鏡誌、2004；20：70-73.

11）中村弘治 他：腹望鏡下で治療を行った原発性腹膜妊 娠の1例、日産婦東京会誌、2005；54：37-40.

12) Siow A, et al.: Successful laparoscopic treatment of an abdominal pregnancy in the broad ligament. Singapore Med J 2004; 45: 88.

13）合志礼子 他：腹脭鏡下に治療しえた膀胱子宮窩腹膜 に着床した腹膜妊娠の1症例、日産内視鏡誌、2010； $26: 383-387$.

14) Takeda A, et al.: Management of patients with ectopic pregnancy with massive hemoperitoneum by laparoscopic surgery with intraoperative autologous blood transfusion. J Minim Invasive Gynecol 2006; 13: 43-48.

15) Crespo R, et al.: Successful methotrexate treatment of an abdominal pregnancy in the pouch of douglas. Clin Exp Obstet Gynecol 2008; 35: 289-290.

16) Cobellis L, et al: Contribution to the choice of therapy in abdominal pregnancy. Panminerva Medica 2000; 42: 159.

17) James NM, et al.: Abdominal pregnancy: current concept of management. Obstet Gynecol 1988; 4: 549-557.

18) Hwa Seon Koo, et al.: Laparoscopic management of early primary peritoneal pregnancy: a case report. Clin Exp Reprod Med 2011; 38: 109-114.

19) del Rosario R, El-Roeiy A.: Abdominal pregnancy on the bladder wall following embryo transfer with cryopreserve-thawed embryos: a case report. Fertil Steril 1996; 66: 839.

20) Koo HS, et al.: Laparoscopic management of early primary peritoneal pregnancy: a case report. Clin Exp Reprod Med 2011; 38: 109-114.

21）香川愛子 他：腹胿鏡で治療しえた腹胿妊娠の2例、 日産婦神奈川会誌、2011; 47：34-36.

22）山本 直 他：腹胫鏡で診断治療された腹膜妊娠の 1 例、日本産科婦人科学会熊本地方部会雑誌、2010 ; $54: 107-109$.

23）中澤 学 他：腹胿鏡下手術で診断しえた腹膜妊娠の 1例、長野赤十字病院医誌、 $2008 ; 22: 20-22$.

24) Sadro Gerli, et al.: Early ultrasonographic diagnosis and laparoscopic treatment of abdominal pregnancy. Eur J Obstet Gynecol Reprod Biol 2004; 15: 103-105.

25）興石太郎 他：腹胿鏡により診断治療しえた腹腔娃娠 の1例、日産婦東京会誌、2004; $52: 317-321$.

26）三浦成陽 他：腹腔鏡下に処置できた腹膜妊娠の2例、 日産内視鏡誌、2004；20：133-136.

27）岡本恵理、武曽 博、宇田 聡：腹胿鏡検查で明ら かとなった腹膜妊娠の1症例、済生会千里病医誌、 $2004 ; 15: 48-50$.

28) C. K. Chang, et al.: Primary omental pregnancy treated by laparoscopic surgery. Int J Gynaecol Obstet 2003; 80: 325-326.

29) Ming-Ting Chung, et al.: Laparoscopic surgery for omental pregnancy. J Am Assoc Gynecol Laparosc 2002; 9: 84-86.

30) Adrian Kwok, et al.: Laparoscopic management of a case of abdominal ectopic pregnancy. Aust N Z J Obstet Gynaecol 2002; 42: 300-302.

31）仲村光世 他 : 腹胿鏡にて診断、治療した腹膜妊娠の 一例、日生医誌、2003; $31: 49-52$.

32）矢野樹理：腹腔妊娠、臨婦産、 $2001 ; 55: 1008-1010$.

33）千々和真理 他：早期骖断により腹腔鏡治療が可能で あった腹胿妊娠の一例、産婦人科治療、2001；83： 
118-121.

34）斉藤正博 他：顕微授精・肧移植後に腹腔妊娠となっ た1例、産科と婦人科、2001; $5: 667-670$.

35) Ginath S, et al.: Successful laparoscopic treatment of a ruptured primary abdominal pregnancy. Fertil Steril 2000; 74: 601-602.

36) J. P. Geisler, et al.: Successful laparoscopic treatment of abdominal pregnancy in the posterior cul-de-sac. Clin Exp Obstet Gynecol 2000; 27: 83-84.

37) Martin E. Olsen: Laparoscopic treatment of intraligamentous pregnancy. Obstet Gynecol 1997; 89: 862.

38) Z.Ben-Rafael, et al.: Laparoscopic removal of an abdominal pregnancy adhere to the appendix after ovulation induction with human menopausal gonadotrophin. Hum Reprod 1995; 10: 1804-1805.

39) Richard W. Dover, et al.: Managemant of primary abdominal pregnancy. Am J Obstet Gynecol 1995; 172: 1603-1604. 